\title{
Bellulicauda dialii on Dialium guianense (Leguminosae) in Brazil
}

\author{
Olinto L. Pereira ${ }^{1 *}$, Lorrayne B. Bosquetti ${ }^{2} \&$ Robert W. Barreto ${ }^{1}$ \\ Universidade Federal de Viçosa, ${ }^{1}$ Departamento de Fitopatologia, ${ }^{2}$ Departamento de Biologia Vegetal, \\ CEP36571-000, Viçosa, MG, e-mail: liparini@bol.com.br \\ (Accepted for publication on 14/07/2004)
}

Corresponding author: Olinto L. Pereira

PEREIRA, O.L., BOSQUETTI, L.B. \& BARRETO, R.W. Bellulicauda dialii on Dialium guianense (Leguminosae) in Brazil. Fitopatologia Brasileira 30:79-80. 2005.

\begin{abstract}
This is the first report of Bellulicauda dialii on Dialium guianense leaves, and the second record of this fungus, previously known only from Africa (Sierra Leone).

Additional keywords: Coelomycetes, Caesalpinioideae, Fabaceae, forest pathology.

\section{RESUMO}

Bellulicauda dialii em Dialium guianense (Leguminosae) no Brasil

Bellulicauda dialii é relatado pela primeira vez em folhas de Dialium guianense. Trata-se do segundo registro dessa espécie fúngica, anteriormente conhecida apenas do Continente Africano (Serra Leoa).

Palavras-chave adicionais: Coelomicetos, Caesalpinioideae, Fabaceae, patologia florestal.
\end{abstract}

Dialium guianense (Aublet) Sandw. [Leguminosae (Caesalpinioideae)], is a native tree to Central and South America (Lewis, 1987; Lewis \& Owen, 1989). The wood of this species is used for multiple purposes and the fruits are consumed mainly for their fleshy edible mesocarp and commonly found for sale in street markets in some cities in the states of Bahia and Espírito Santo (Lorenzi, 1998). In February 2002, during a survey of the mycobiota associated with some members of Leguminosae in the Parque Estadual do Rio Doce (PERD), municipality of Marliéria, state of Minas Gerais, a foliicolous fungus was observed attacking D. guianense at Lagoa dos Patos (Trilha da Mumbaça). Infected leaves were collected, photographed and dried for deposit in herbarium. Isolation from fresh material was attempted on VBA medium (Pereira et al., 2003) both directly and indirectly followed by incubation in the dark for $48 \mathrm{~h}$ at $25^{\circ} \mathrm{C}$ and later submittion to $12 \mathrm{~h}$ near ultra violet radiation/ $12 \mathrm{~h}$ dark (Leach, 1962) in plastic petri dishes at $25^{\circ} \mathrm{C}$. Observations and measurements were made from dried herbarium specimens. Sections were cut using a freezing microtome (Leitz Kryomat), adjusted to a thickness of $30 \mu \mathrm{m}$, mounted in lactophenol, and observed and photographed with a light microscope (Olympus BX 50).

The fungus was identified as Bellulicauda dialii (Sydow) Sutton, which had been reported on D. angolense Oliver and $D$. guineense Willd only from Sierra Leone (Africa) (Sutton, 1980). The genus Bellulicauda Sutton was based on Diachorella dialii Sydow, and then excluded from the genus Diachorella (Sutton, 1967). The genus is still monotypic (Nag Raj, 1993).

Morphological features of the fungus (VIC 26563):
Lesions poorly delimited, amphigenous, consisting of groups of conidiomatal stromatic clypei (Figure 1A, B), with no sign of necrotic tissue surrounding the fruit-bodies, similar to small tar-spots caused by Phyllachora spp. on some leguminous hosts, Mycelium immersed, branched, septate, pale brown, 3.5-5.0 $\mu \mathrm{m}$ diam, Conidiomata stromatic, amphigenous, scattered, discrete, immersed, roughly oval, gregarious, 350$700 \times 175-225 \mu \mathrm{m}$ diam. (Figure 1C). Locule irregulary convoluted, ostiolate, Conidiomata wall with "textura globulosa", consisting of dark brown thick-walled cells, forming a black stroma, 25-50 $\mu \mathrm{m}$ wide, in the upper and lower epidermis, gradually merging with pale brown, thin-walled cells lining the conidiomatal cavity. In some cases, the stromatic clypeus extends laterally to the conidioma, completely surrounding it (Figure 1D) (a previously unreported morphological feature for this fungus). Ostiole slightly papillate, circular, up to $20 \mu \mathrm{m}$ diam. Conidiophores arising from the inner cells of the walls, cylindrical, aseptate, unbranched, hyaline, smooth, invested in mucus (Figure 1E), 9.0-15.5 X 3.0-5.0 $\mu \mathrm{m}$. Conidiogenous cells holoblastic, ampulliform to subcylindrical, hyaline, smooth. Conidia ellipsoid, aseptate, $10-13 \times 4.0-7.0 \mu \mathrm{m}$, base truncate, apex obtuse, pale brown, thick walled and smooth with part of the conidiogenous cell attached to the base, with an intervening septum, appearing as a cellular, hyaline, subcylindrical, unbranched frill (Figure 1F).

The attempt to isolate $B$. dialii in culture was unsuccessful suggesting that this fungus is biotrophic.

The complete geographic distribution of $B$. dialii remains unknown but this new record from Brazil suggests that this fungus has a wide distribution accompanying the host genus distribution. 

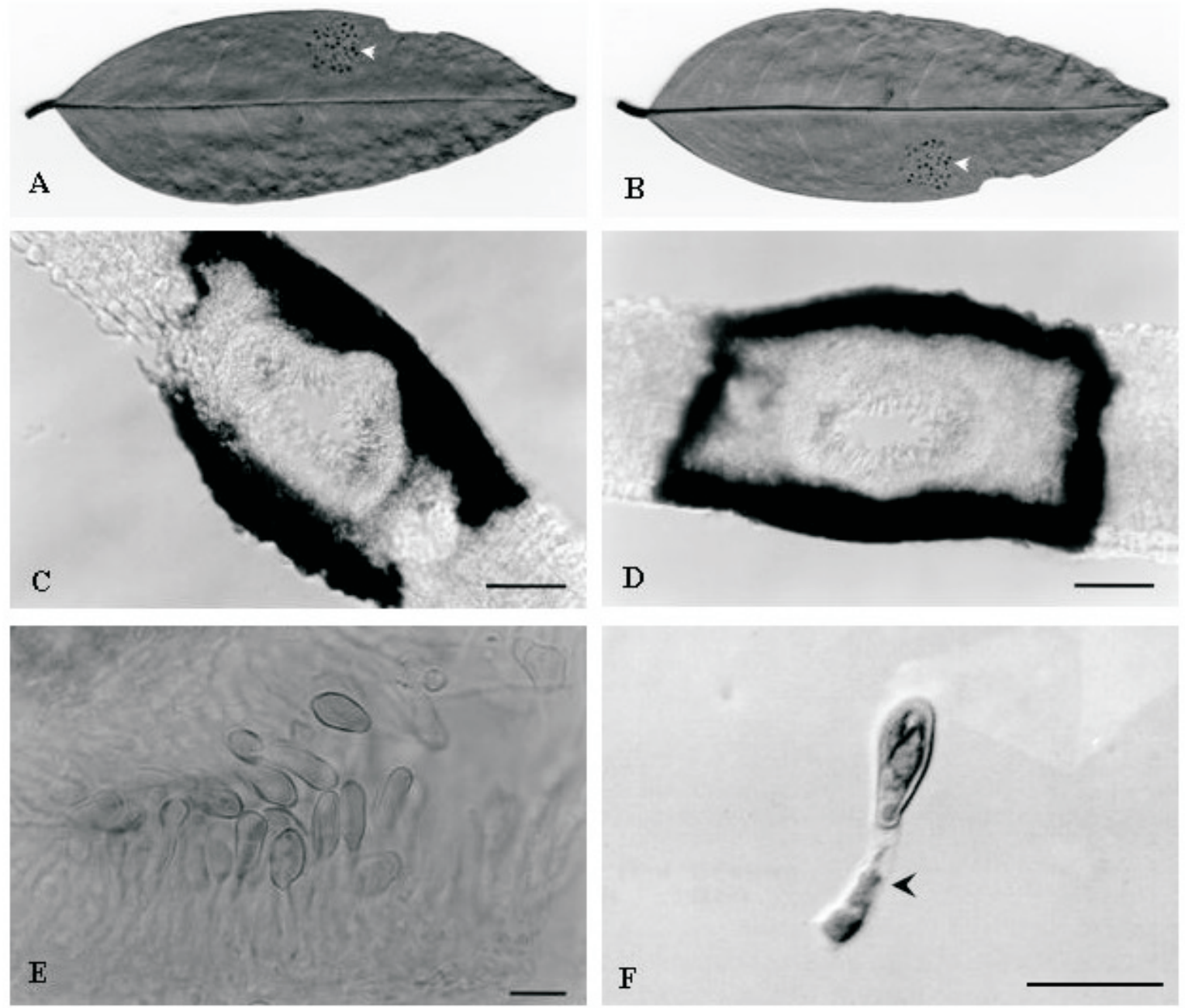

FIG. 1 - Bellulicauda dialii. Poorly delimited leaf lesions composed of black stromatic conidiomata in the upper (A) and lower (B) leaf surfaces (arrowheads). Cross section of leaf showing the stromatic conidioma partially (C) and completely (D) surrounded by a thick black stromatic clypeus. Partial sectional view of conidial hymenium invested in mucus (E). Mature thick walled ellipsoid conidia with a basal thin-walled elongated frill (arrowhead) $(\mathrm{F})$. [Bars $=70 \mu \mathrm{m}(\mathrm{C}, \mathrm{D}) ; 10$ $\mu \mathrm{m}(\mathrm{E}, \mathrm{F})]$.

\section{ACKNOWLEDGEMENTS}

The authors thank Mr. W. Q. dos Santos and Mr. G. Adriano for assistance during field work and the Director of the Parque Estadual do Rio Doce for the use of the facilities. O.L. Pereira and R. W. Barreto also thank the Conselho Nacional de Desenvolvimento Científico e Tecnológico (CNPq) for financial support.

\section{LITERATURE CITED}

LEACH, C.M. Sporulation of diverse species of fungi under nearultraviolet radiation. Canadian Journal of Botany 40:151-161. 1962. LEWIS, G.P. Legumes of Bahia. Kew. Royal Botanic Gardens. 1987.
LEWIS, G.P. Legumes of the Ilha de Maracá. Kew. Royal Botanic Gardens. 1989.

LORENZI, H. Árvores Brasileiras: manual de identificação e cultivo de plantas arbóreas nativas do Brasil. Nova Odessa. Editora Plantarum. 1998.

NAG RAJ, T.F. Coelomycetous anamorphs with appendage-bearing conidia. Ontario. Mycologue Publications. 1993.

PEREIRA, J.M., BARRETO, R.W., ELLISON, A.C. \& MAFFIA, L.A. Corynespora casiicola f. sp. lantanae:a potential biocontrol agent from Brazil for Lantana camara. Biological Control 26:2131. 2003.

SUTTON, B.C. The Coelomycetes. Kew. Commonwealth Mycological Institute. 1980.

SUTTON, B.C. Two new genera of the Sphaeropsidales and their relationships with Diachorella, Strasseria and Plagiorhabdus. Canadian Journal of Botany 45:1249-1263. 1967. 